\title{
BRCA2 wt Allele
}

National Cancer Institute

\section{Source}

National Cancer Institute. BRCA2 wt Allele. NCI Thesaurus. Code C52061.

Human BRCA2 wild-type allele is located in the vicinity of $13 q 12.3$ and is approximately 84 $\mathrm{kb}$ in length. This allele, which encodes breast cancer type 2 susceptibility protein, is involved in double-stranded DNA break repair, homologous recombination and transcriptional regulation. Certain allelic variants of the BRCA2 gene are associated with early-onset breast cancer, prostate cancer and Fanconi anemia. 